\author{
Kinga Konieczna ${ }^{\text {a) }}$ \\ (D) https://orcid.org/0000-0003-1886-2963
}

\title{
Pozycja prawna notariusza w sprawach spadkowych o charakterze transgranicznym Glosa do wyroku Trybunału Sprawiedliwości Unii Europejskiej w sprawie C-658/17 WB ${ }^{1}$
}

\begin{abstract}
The commentary presents an analysis of a thesis presented by the Court of Justice of the European Union in Judgment of 23rd of May 2018. The question referred to the Court in case C-658/17 WB concerned legal definition of a ,court' and legal classification of the national deed of certification of succession under the provisions of Regulation (EU) No 650/2012. The Judgment states that notary in Poland that draw up a deed of certificate of succession at the unanimous request of all the parties, does not constitute a ,court' within the meaning of that provision. Subsequently, a deed drawn up by such authority does not constitute a 'decision' within the meaning of that provision. The Judgment is particularly relevant since its impact extends to national certificates of succession issued by notaries in other countries, that are part of the Latin part notary system. In conclusion it is indicated, that the Judgment rendered by Tribunal, although highly rightful, relates to merely one of numerous issues concerning use of authentic documents in cross-border succession cases.
\end{abstract}

Keywords: Regulation (EU) 650/2012, succession, deed of succession certification, notary public

a) Mgr, asystent w Zakładzie Prawa Prywatnego Międzynarodowego w Katedrze Prawa Cywilnego Wydziału Prawa i Administracji Uniwersytetu Gdańskiego.

${ }^{1}$ Wyrok TSUE z dnia 23 maja 2019 r. w sprawie WB, C-658/17. ECLI:EU:C:2019:444. 


\section{Uwagi wstępne}

Europejskie poświadczenie spadkowe wprowadzone zostało rozporzadzeniem 650/2012 w sprawie jurysdykcji, prawa właściwego, uznawania i wykonywania orzeczeń, przyjmowania i wykonywania dokumentów urzędowych dotyczacych dziedziczenia oraz $\mathrm{w}$ sprawie ustanowienia europejskiego poświadczenia spadkowego ${ }^{2}$ [dalej: Rozporządzenie]. W założeniu miało ono ułatwić legitymowanie następców spadkowych oraz wykazywanie przez nich uprawnień do zarządzania majątkiem spadkowym $\mathrm{w}$ sprawach o charakterze transgranicznym. Instrument ten jest uznawany we wszystkich państwach członkowskich Unii Europejskiej bez potrzeby przeprowadzania odrębnych postępowań spadkowych w każdym z nich. Zamierzonym efektem jego wprowadzenia było ujednolicenie rozstrzygnięć $\mathrm{w}$ sektorze transgranicznych spraw spadkowych na obszarze Unii Europejskiej, a tym samym zwiększenie przejrzystości i pewności obrotu prawnego. Miał on również odciążyć sądy oraz uzupełnić luki w krajowych systemach prawnych. Rozwiązania zawarte w unijnej regulacji w sprawach dziedziczenia jeszcze przed wejściem w życie wymienionego Rozporządzenia bywały oceniane jako kontrowersyjne ${ }^{3}$. Zgłaszane wattpliwości dotyczyły przede wszystkim istnienia kompetencji Unii Europejskiej w zakresie harmonizacji tej dziedziny prawa. Postępująca migracja w Europie oraz powszechność nabywania przez obywateli Unii mienia w innych państwach członkowskich okazały się czynnikami, które przeważyły na rzecz standaryzacji reguł prawa materialnego $\mathrm{w}$ transgranicznym prawie dziedziczenia ${ }^{4}$. Celem takiego działania było dostosowanie ich do potrzeb obrotu prawnego w erze postępującej globalizacji. Z biegiem czasu okazało się, że unijna regulacja nie jest jednak kompleksowa, a mankamenty tyczą się przede wszystkim względów proceduralnych.

${ }^{2}$ Rozporządzenie Parlamentu Europejskiego i Rady (UE) nr 650/2012 z dnia 4 lipca 2012 r. w sprawie jurysdykcji, prawa właściwego, uznawania i wykonywania orzeczeń, przyjmowania i wykonywania dokumentów urzędowych dotyczących dziedziczenia oraz w sprawie ustanowienia europejskiego poświadczenia spadkowego. Dz.Urz. UE L nr 201 z 2012 r., s. 107.

${ }^{3}$ E.B. Crawford, J.M. Carruthers: Speculation on the Operation of Succession Regulation 650/2012: Tales of Unexpected. „22 European Review of Private Law” 2014, Issue 6, s. 847-878.

${ }^{4}$ M. Załucki: New revolutionary regulation on succession matters. Key issues and doubts. „Revista de derecho civil” 2016, vol. 3, n 1, s. 165-176. 


\section{Stan faktyczny w sprawie C-658/17}

W orzeczeniu wydanym w dniu 23 maja 2019 r. Trybunał Sprawiedliwości Unii Europejskiej podjął się udzielenia odpowiedzi na pytanie, jakie przedstawił Sąd Okręgowy w Gorzowie Wielkopolskim. Postępowanie sądowe $\mathrm{w}$ tej sprawie zainicjowało zażalenie $\mathrm{w}$ przedmiocie odmowy dokonania czynności notarialnej, złożone do sądu przez zastępcę notarialnego. Skarżąca domagała się wydania przez zastępcę notarialnego wypisu aktu poświadczenia dziedziczenia wraz z zaświadczeniem potwierdzajaccym, że akt ten stanowi orzeczenie w sprawie dotyczącej dziedziczenia w rozumieniu Rozporządzenia spadkowego. Na wypadek nieuwzględnienia tego wniosku wnosząca zażalenie zażądała wydania wypisu aktu poświadczenia dziedziczenia wraz z zaświadczeniem potwierdzającym, że stanowi on „dokument urzędowy dotyczący dziedziczenia". Zastępca notarialny odmówił wydania któregokolwiek z zaświadczeń. Uzasadniając odmowę, przedstawił argument, że akt poświadczenia dziedziczenia spełnia wprawdzie kryteria niezbędne do uznania go za orzeczenie (określone $\mathrm{w}$ art. 3 ust. 1 pkt g i ust. 2 Rozporządzenia), jednak państwo polskie nie dopełniło obowiązku powiadomienia Komisji o objęciu polskich notariuszy zakresem pojęcia „sąd”, wynikającego z art. 79 Rozporządzenia 650/2012. Takie zaniechanie wykluczyło zaś dopuszczalność wydania zaświadczenia stwierdzającego, że akt poświadczenia dziedziczenia stanowi orzeczenie na gruncie przepisów Rozporządzenia. Natomiast okoliczność, że dokument notarialny spełnia określone $\mathrm{w}$ Rozporządzeniu formalne kryteria uznania go za orzeczenie w ocenie zastępcy wyeliminowała możliwość uznania go za dokument urzędowy. Sąd rozstrzygający sprawę zwrócił uwagę na niejasny charakter zawartego w art. 3 ust. 2 in fine Rozporządzenia obowiązku notyfikacji Komisji organów lub przedstawicieli zawodów prawniczych, które spełniają określone w tym ustępie kryteria uznania ich za „sąd”. Z treści przepisu nie wynika, czy charakter prawny tego obowiązku należy zakwalifikować jako konstytutywny, czy też wyłącznie informacyjny. Sąd zaakcentował ponadto brak precyzji prawodawcy unijnego przy definiowaniu $\mathrm{w}$ treści Rozporządzenia pojęć „orzeczenie” i „sąd”. Wskazał, że w prawie polskim — w myśl art. 95 j ustawy Prawo o notariacie ${ }^{5}$ — zarejestrowany akt poświadczenia dziedziczenia ma skutki prawomocnego postanowienia o stwierdzeniu nabycia spadku, nie jest jednak jasne, czy pojęcie „orzeczenie" implikuje wydanie takiego aktu przez instytucję posiadająca

${ }^{5}$ Ustawa z dnia 14 lutego 1991 r. - Prawo o notariacie. T.j. Dz.U. 2019, poz. 540, 730, 1495, 1655, 2020. 
kompetencje do orzekania w kwestiach spornych między stronami oraz czy uznanie danego aktu za orzeczenie wyklucza możliwość uznania go za dokument urzędowy. Jako że jednolita interpretacja wskazanych pojęć we wszystkich państwach członkowskich UE jest kluczowa dla zapewnienia spójności oraz poprawności stosowania wspólnej regulacji spadkowej, sąd skierował do Trybunału pytania prejudycjalne odnoszące się do opisanych wyżej zagadnień.

\section{Rozstrzygnięcie Trybunału}

W wyroku wydanym na kanwie niniejszej sprawy Trybunał orzekł, że związanie notariuszy w danym państwie członkowskim zasadami jurysdykcji określonymi w Rozporządzeniu powinno zależeć od tego, czy są oni objęci zakresem definicji „sąd” do celów niniejszego rozporządzenia, a nie od ujęcia ich przez państwo w wykazie, o którym mowa $\mathrm{w}$ art. 79 Rozporządzenia. Tym samym przewidziany w art. 3 Rozporządzenia obowiązek notyfikowania Komisji organów lub przedstawicieli zawodów prawniczych, które spełniaja kryteria uznania ich za „sąd”, ma charakter wyłącznie informacyjny. Trybunał nie przychylił się więc do przedstawionego stanowiska zastępcy notarialnego. W rozstrzygnięciu przypomniał o nadrzędnym celu Rozporządzenia, którym powinno być zapewnienie należytego działania wymiaru sprawiedliwości w Unii Europejskiej. Wskazał, że dopuszczenie do uznaniowych decyzji państw członkowskich - w oderwaniu od wymogów sformułowanych w przepisach Rozporządzenia - o umieszczeniu organów lub przedstawicieli zawodów prawniczych w wykazie stanowiłoby dla jego realizacji poważne zagrożenie. $\mathrm{W}$ odniesieniu do charakteru prawnego kompetencji polskiego notariusza Trybunał podkreślił, że aby dany organ mógł zostać uznany za wykonujący funkcje sądowe, musi być umocowany do rozstrzygnięcia ewentualnego sporu. Sytuacja taka nie ma miejsca w przypadku, gdy kompetencje danego przedstawiciela zawodu prawniczego zależa tylko i wyłącznie od woli stron. Dlatego też pozycja prawna notariusza w Polsce nie pozwala, zdaniem Trybunału, na objęcie go zakresem pojęcia „sąd” oraz na uznanie wydawanego przez niego aktu poświadczenia dziedziczenia za orzeczenie w rozumieniu przepisów Rozporządzenia $650 / 2012$. 


\section{Usytuowanie notariusza w sprawach spadkowych w polskim porządku prawnym}

Rozstrzygnięcie w sprawie C-658/17 ma doniosłe znaczenie praktyczne. Wykładnia dokonana przez Trybunał położyła kres jednej z wielu istotnych wątpliwości związanych ze stosowaniem regulacji Rozporządzenia w obrocie prawnym i stanowi przełom w zapatrywaniach prawodawcy unijnego na rolę notariusza $\mathrm{w}$ systemie organów ochrony prawnej. Wcześniej tematyka ta była podejmowana w literaturze, zachodziły jednak rozbieżności w poglądach prezentowanych przez poszczególnych autorów, które przedstawię pokrótce $\mathrm{z}$ uwagi na zwięzłość niniejszego opracowania. Część przedstawicieli nauki uważała, że okoliczność, że akt poświadczenia dziedziczenia wydawany jest z urzędu, po uprzednim sporządzeniu protokołu dziedziczenia na żądanie stron, zbliża charakter prawny czynności notariusza do zadań wykonywanych przez sąd w sprawach niespornych ${ }^{6}$. Dla uzasadnienia takiej koncepcji przywoływany bywał przepis art. 95 j ustawy Prawo o notariacie, zrównujący zarejestrowany akt poświadczenia dziedziczenia z prawomocnym postanowieniem sadowym ${ }^{7}$. Wskazywano, że tryb sporządzenia aktów poświadczenia dziedziczenia daje gwarancje bezstronności i prawa wszystkich stron do bycia wysłuchanym ${ }^{8}$. Zdecydowany postulat uznania notariusza za sąd w rozumieniu Rozporządzenia zgłaszał także T. Kot. Autor ten przedstawił godną uwagi tezę, że dzięki takiemu zapatrywaniu notariat staje się organem prewencyjnej ochrony prawnej w sprawach cywilnych. Opowiedział się za tym, aby w sprawach cywilnych postępowanie przed notariuszem było traktowane jako postępowanie przed sądem pierwszej instancji, z możliwością odwołania się do sądu9. W nauce spotkać można również pogląd, że sporządzenie aktu poświadczenia dziedziczenia na-

${ }^{6}$ M. Walasik: Pozycja prawna notariusza $w$ sprawach międzynarodowych $z$ zakresu prawa spadkowego. W: Znad granicy ponad granicami. Ksiega jubileuszowa Profesora Dietera Martiny. Red. M. Krzymuski, M. Margoński. Warszawa 2014, s. 352 i n. P. Czubik zwraca uwagę, że notariusz może być potencjalnie uznany za sąd w rozumieniu art. 3 ust. 2 Rozporządzenia, jednak przepisy Prawa o notariacie stoją temu na przeszkodzie. Autor ten zauważa potrzebę zmiany w tym zakresie. Zob. P. Czubik: Konsekwencje europejskiego rozporzadzenia spadkowego ( $n$ r 650/2012) dla praktyki notarialnej (zagadnienia dotyczqce wyboru prawa właściwego dla dziedziczenia). „Rejent” 2013, nr 11, s. 29-30.

${ }^{7}$ Ustawa z dnia 14 lutego 1991 r. - Prawo o notariacie...

${ }^{8}$ M. Walasik: Pozycja prawna notariusza..., s. 352 i n.

9 T. Kot: Czy polski notariusz może być sqdem na gruncie rozporzqdzenia spadkowego? Gtos w dyskusji. W: Nowe europejskie prawo spadkowe. Red. M. Pazdan, J. Górecki. Warszawa 2015, s. 92-93. 
leży do czynności prawnych sui generis, których nie można zakwalifikować ani do kategorii aktów notarialnych, ani też do „zwykłych” poświadczeń $^{10}$. Istota sporządzanego przez notariusza poświadczenia sprowadza się do złożenia przez niego oświadczenia wiedzy co do własnoręczności podpisu, pozostawania danej osoby przy życiu lub w określonym miejscu oraz innych stanów rzeczy, o których mowa w art. 96 Prawa o notariacie. Tymczasem wydanie aktu poświadczenia dziedziczenia nie ma na celu ustalenia wiedzy o faktach, lecz potwierdzenie stanu prawnego. Warto zauważyć, że w wyniku zmian wprowadzonych przez ustawodawcę w 2015 r. na poświadczeniu obecnie podpisuje się wyłącznie notariusz. Zdaniem M. Pazdana, rezygnacja z podpisywania dokumentu przez pozostałe osoby zainteresowane miała za zadanie zaakcentowanie judykacyjnej roli notariusza względem aktów potwierdzających prawa do spadku ${ }^{11}$. W przedmiocie usytuowania notariusza wśród przedstawicieli innych zawodów prawniczych wypowiedział się także Trybunał Konstytucyjny. W wyroku z dnia 10 grudnia 2003 r. zajął on stanowisko, że notariusz w polskim systemie prawnym jest nie tylko osobą zaufania publicznego, lecz pełni jednocześnie funkcje pomocnicze w stosunku do wymiaru sprawiedliwości, dokonując czynności, przy których udział notariusza ma charakter obligatoryjny oraz nadaje sporządzonym dokumentom szczególny walor dowodowy - moc dokumentu urzędowego. Przedstawiciele tego zawodu korzystaja ponadto z ochrony przysługujacej funkcjonariuszom publicznym (na mocy art. $2 \S 1$ ustawy Prawo o notariacie), wykonuja szereg czynności o charakterze urzędowym (m.in. działając jako płatnicy podatków i opłat skarbowych), a swoboda kształtowania przez nich wynagrodzenia za dokonane czynności jest w znacznym stopniu ograniczona. W ocenie Trybunału Konstytucyjnego te aspekty niewątpliwie wskazuja na szczególną pozycję notariuszy względem podmiotów świadczących typowe usługi prawnicze ${ }^{12}$. Przeciwko uznaniu aktu poświadczenia dziedziczenia za akt notarialny przedstawiane były argumenty odnoszące się zarówno do systematyki Prawa o notariacie, jak i do braku w jego treści jakichkolwiek oświadczeń stron (taki element aktu notarialnego określony jest jako konstytutywny w art. 92 ustawy Prawo o notariacie). Zwracano również uwagę na odmienną niż w przypadku aktu notarialnego pro-

${ }^{10}$ P. Księżak: Charakter prawny aktu poświadczenia dziedziczenia. W: Notarialne poświadczenie dziedziczenia. Zagadnienia wybrane. Red. A. Marciniak. Warszawa 2019, s. 4.

${ }^{11}$ M. Pazdan: Notarialne poświadczenie dziedziczenia po zmianach z 2015 roku. „Rejent” 2016, nr 4, s. 21. Autor wskazuje ponadto, że owa judykacyjna rola jest szczególnie widoczna przy wydawaniu przez notariuszy europejskich poświadczeń spadkowych.

12 Wyrok Trybunału Konstytucyjnego z dnia 10 grudnia 2003 r., K 49/2001. OTK ZU 2003, nr 9A, poz. 101. 
cedurę jego uchylenia ${ }^{13}$. W ocenie M. Setkowicz czynności wykonywane przez notariusza należą wprawdzie do zadań z zakresu ochrony prawnej, jednak nie można ich uznać za zadania z zakresu wymiaru sprawiedliwości, polegające na rozstrzyganiu sporów, które zgodnie z art. 175 Konstytucji RP zastrzeżone sa dla sądów ${ }^{14}$. Przeciwko uznaniu notariuszy za sąd (z uwagi na okoliczność, że wydawane przez nich dokumenty nie są orzeczeniami) opowiedział się także J. Pisuliński ${ }^{15}$.

\section{Ocena stanowiska Trybunału}

Niejednolite postrzeganie charakteru prawnego czynności dokonywanych przez notariuszy miało zauważalne przełożenie na praktykę. Wątpliwości dotyczyły nie tylko czynności z zakresu prawa spadkowego, lecz także prawa rzeczowego - niejasne było bowiem, czy sąd w celu usunięcia niezgodności między treścią księgi wieczystej a rzeczywistym stanem prawnym może dokonać wpisu do księgi wieczystej na podstawie wniosku zawartego $\mathrm{w}$ zagranicznym odpowiedniku aktu poświadczenia dziedziczenia, traktując taki dokument na równi z orzeczeniem sądu, o którym mowa w art. 31 ust. 2 ustawy o księgach wieczystych i hipote$\mathrm{ce}^{16}$. Rozstrzygnięcie Trybunału w sprawie C-658/17 przyczyni się do jednolitego ujęcia statusu dokumentu notarialnego w podobnych sprawach. Trybunał rozstrzygnął, że za „sąd” na gruncie Rozporządzenia może być uznany wyłącznie organ, który zapewnia gwarancję bezstronności i prawa wszystkich stron do bycia wysłuchanymi, a jego orzeczenia mogą być przedmiotem zaskarżenia do organu sądowego lub ponownego rozpoznania przez organ sądowy oraz mają moc i skutek podobne do orzeczenia organu sądowego w takiej samej sprawie. Ponadto musi on mieć kompetencje do rozpatrzenia sprawy potencjalnie spornej pomiędzy stronami,

${ }^{13}$ P. Księżak: Charakter prawny aktu poświadczenia dziedziczenia..., s. 1-15.

${ }_{14}$ M. Setkowicz: Notariusz jako organ ochrony prawnej $w$ świetle prawa polskiego i prawa Unii Europejskiej. „Przegląd Prawa i Administracji” 2016, T. 107, s. 203.

${ }_{15}$ J. Pisuliński: Wprowadzenie. W: Europejskie prawo cywilne. Warszawa 2013, s. 23.

${ }_{16}$ Por. stan faktyczny postanowienia Sądu Okręgowego w Gliwicach z dnia 19 kwietnia 2017 r., III Ca 391/17, https://www.saos.org.pl/judgments/298662, w którym przedmiotem zaskarżenia stało się orzeczenie Sądu Rejonowego w Raciborzu, w którym sąd ten uznał poświadczenie spadkowe sporządzone przez notariusza w Niemczech za orzeczenie; ocenił jednak, że nie może być ono podstawą wpisu do księgi wieczystej z uwagi na brak informacji o tym, czy jest ono prawomocne. 
a taka sytuacja nie ma miejsca, gdy - tak jak w przypadku polskich notariuszy - jego kompetencje zależą wyłącznie od woli stron. Słusznie podkreślono, że notariusze w Polsce wykonują wolny zawód — w ramach prowadzonej działalności dokonują czynności za wynagrodzeniem określonym na podstawie umowy z osobami stawającymi do czynności. W połączeniu z brakiem uprawnień decyzyjnych $\mathrm{w}$ sprawach spadkowych dodatkowo przemawia to przeciwko uznaniu ich za organy wykonujace funkcje sądowe. Stanowisko Trybunału jest spójne z wcześniejszymi poglądami na rolę notariuszy $\mathrm{w}$ systemie prawnym, zawartymi w orzeczeniach w sprawach C-551/15 (Pula Parking) ${ }^{17}$ i C-484/15 (Zulfikarpašić) ${ }^{18}$, co pozytywnie wzmacnia jego wydźwięk. Trudno jednak zakładać, że jednoznacznie położy ono kres istniejącym $\mathrm{w}$ doktrynie wątpliwościom co do statusu notariusza $\mathrm{w}$ polskim systemie prawnym - rozważania Trybunału dotyczą w głównej mierze autonomicznego znaczenia pojęcia „sąd” na gruncie postanowień Rozporządzenia 650/2012.

Argumentacja przedstawiona $\mathrm{w}$ glosowanym orzeczeniu zasługuje na aprobatę oraz rozwinięcie. W uzasadnieniu rozstrzygnięcia $\mathrm{w}$ sprawie C-658/17 wyraźnie zaakcentowano znaczenie autonomicznej wykładni niektórych pojęć na gruncie prawa UE. Pojęcie sądu zostało poddane interpretacji przede wszystkim przez pryzmat potencjalnie spornego charakteru rozpoznawanych spraw ${ }^{19}$. Chociaż stanowisko Trybunału spotkało się z krytycznymi ocenami niektórych przedstawicieli nauki ${ }^{20}$, warto zwrócić uwagę, że notariusz nie tylko nie rozpatruje spraw potencjalnie spornych, lecz także postępowanie przed tym organem nie ma charakteru kontradyktoryjnego. Brak w nim ponadto kontroli instancyjnej, która stanowi jedna z podstawowych cech postępowania przed sądem - zarejestrowanie aktu poświadczenia dziedziczenia jest swoistym nadaniem mu waloru prawomocności. Wprawdzie - zgodnie z art. 95 j ustawy Prawo o notariacie - zarejestrowany akt poświadczenia dziedziczenia ma skutki prawomocnego postanowienia o stwierdzeniu nabycia spadku, jednak dokumenty wydawane przez notariuszy maja słabsza moc niż orzeczenia sądowe wydawane w sprawach spadkowych. Wniosek taki można wyprowadzić z art. $669^{1}$ Kodeksu postępowania cywilnego [dalej: k.p.c.], zgodnie z którym są spadku uchyla zarejestrowany akt poświadczenia dziedziczenia, jeżeli w odniesieniu do tego samego spadku zostało wydane postanowienie o stwierdzeniu

17 Wyrok TSUE z dnia 9 marca 2017 r., C-551/15. ECLI:EU:C:2017:193.

18 Wyrok TSUE z dnia 9 marca 2017 r., C-484/15. ECLI:EU:C:2017:199.

19 B. Trocha: Akt poświadczenia dziedziczenia w świetle prawa UE. Glosa do wyroku TS z dnia 23 maja 2019 r., C-658/17. LEX.

${ }^{20}$ P. Księżak: Charakter prawny aktu poświadczenia dziedziczenia..., s. 1-15. 
nabycia spadku ${ }^{21}$. W przypadku kolizji tych dwóch instytucji pierwszeństwo uzyskuje więc orzeczenie sądu. Wyrazem takiego unormowania jest także art. 1025 k.p.c., który stanowi, że przeciwko domniemaniu wynikającemu ze stwierdzenia nabycia spadku nie można powoływać się na domniemanie wynikające $\mathrm{z}$ aktu poświadczenia dziedziczenia — bez względu na to, czy prawa do spadku zostały najpierw stwierdzone przez sąd, czy przez notariusza. Potwierdzenie praw do spadku należy wyłącznie do kompetencji sądu również w sytuacji, gdy zarejestrowano dwa lub więcej aktów poświadczenia dziedziczenia (zgodnie z art. $669^{1}$ k.p.c.) ${ }^{22}$. Mając na uwadze tak kategoryczne brzmienie przepisów normujących zasady pierwszeństwa pomiędzy tymi dokumentami, wydaje się, że Trybunał trafnie odmówił objęcia polskiego notariusza zakresem znaczeniowym pojęcia „sąd” na gruncie przepisów Rozporządzenia. W przypadku odmiennego rozstrzygnięcia pojęcie to zostałoby poddane wykładni rozszerzającej, której efektem mogłoby być zacieranie się granic pomiędzy władza sądowniczą a przedstawicielami pozostałych profesji prawniczych. W orzeczeniu podkreślono także, że dokonywana przez państwa członkowskie notyfikacja organów, które spełniaja kryteria uznania ich za sąd, choć ustanawia domniemanie, iż organy krajowe zgłoszone zgodnie z art. 79 Rozporządzenia nr 650/2012 stanowia „,sądy” w rozumieniu art. 3 ust. 2 rzeczonego rozporządzenia, ma charakter wyłącznie informacyjny (ang. is of merely indicative value). Również ten element rozstrzygnięcia zasługuje na aprobatę. Przyjęcie innego poglądu powodowałoby, że status „sądu” nie byłby uzależniony od spełnienia kryteriów określonych w art. 3 ust. 2 Rozporządzenia, lecz dodatkowo zostałby uwarunkowany odpowiednia decyzja władz państwa członkowskiego, co w prosty sposób mogłoby otworzyć drogę do nadużyć oraz opóźniłoby przyznanie tym organom kompetencji do działania w sprawach spadkowych. Kwestia notyfikowania przez państwo polskie organów krajowych, które mieszczą się w zakresie pojęcia „sąd”, w rozumieniu Rozporządzenia stała się po wydaniu omawianego orzeczenia bezprzedmiotowa w Polsce bowiem nie istnieją inne poza notariuszem i sądem organy, które sa uprawnione do dokonywania czynności w sprawach spadkowych. Można zatem wyrazić nadzieję, że niniejsze orzeczenie przyczyni się do ujednolicenia $\mathrm{w}$ polskiej doktrynie poglądów w kwestiach proceduralnych. Na chwilę obecną sporne jest bowiem, czy w przypadku złożenia

${ }^{21}$ P. Borkowski trafnie zwraca uwagę, że zgodnie z literalnym brzmieniem przepisu, samo „wydanie” postanowienia o stwierdzeniu nabycia spadku stanowi podstawę do uchylenia zarejestrowanego aktu poświadczenia dziedziczenia. Przepis nie wprowadza bowiem wymogu prawomocności w odniesieniu do postanowienia sądowego. P. Borkowski: Notarialne poświadczenie dziedziczenia. Warszawa 2011, s. 47 i n.

${ }^{22}$ Ibidem, s. 48 i n. 
wniosku o wydanie przez sad postanowienia o stwierdzeniu nabycia spadku w przypadku, gdy w tej samej sprawie został już wydany akt poświadczenia dziedziczenia, wniosek taki może zostać odrzucony z uwagi na stan powagi rzeczy osądzonej ${ }^{23}$, czy też wydanie aktu poświadczenia dziedziczenia nie wywołuje takiego stanu, a wniosek powinien podlegać oddaleniu z uwagi na brak interesu prawnego w uzyskaniu kolejnego dokumentu potwierdzającego prawa do spadku ${ }^{24}$.

\section{Wzajemne uznawanie dokumentów urzędowych w świetle regulacji Rozporządzenia}

Oprócz określenia statusu prawnego dokumentów legitymujących spadkobierców wydawanych przez polskich notariuszy, Trybunał w orzeczeniu w sprawie C-658/17 jednoznacznie potwierdził zasadę wzajemnego uznawania dokumentów urzędowych. Wskazał, że krajowe instrumenty legitymowania spadkobierców przepływają między państwami członkowskimi w trybie Rozporządzenia, niezależnie od wprowadzenia przez prawodawcę unijnego europejskiego poświadczenia spadkowego ${ }^{25}$. Kwestia ta nie była dotychczas jednoznacznie interpretowana w państwach członkowskich. Obowiązek wzajemnego uznawania dokumentów urzędowych, który nie jest zależny od legitymowania się europejskim poświadczeniem spadkowym (stanowiącym instrument fakultatywny), wynika wprost $\mathrm{z}$ art. 59 Rozporządzenia, zgodnie z którym dokumenty urzędowe pochodzace $\mathrm{z}$ innych państw członkowskich zasadniczo maja takie same skutki dowodowe w innych państwach członkowskich. Dopuszczalna jest modyfikacja nadająca dokumentom skutki „najbardziej porównywalne” z tymi, które wywołuja one w państwie członkowskim pochodzenia. Jedynym wyjątkiem, który pozwalałby na odstępstwo od generalnej zasady swobodnego przepływu dokumentów urzędowych, jest oczywista sprzeczność z porządkiem publicznym (ordre public) danego państwa. Takie uregulowanie stanowi w dużej mierze legislacyjne novum, które w założeniu umożliwić ma szybkie i skuteczne załatwienie sprawy spadkowej majacej skutki transgraniczne w UE. Jej zastosowanie w praktyce może

${ }^{23}$ Ibidem, s. 260.

${ }^{24}$ A. Szereda: Art. 951j, w: Czynności notarialne. Komentarz do art. 79-112 Prawa o notariacie. Warszawa 2018, s. 356.

${ }_{25}$ M. Margoński: Art. 62, w: Prawo i postępowanie spadkowe. Komentarz. T. 4 b. Red. K. Osajda. Warszawa 2019. Legalis. 
jednak wiązać się z problemami, wywołanymi przede wszystkim przez zbyt ogólny charakter regulacji oraz brak precyzyjnych wytycznych co do stwierdzania autentyczności i przyjmowania dokumentów urzędowych $\mathrm{w}$ trybie art. 3 i art. 59 Rozporządzenia ${ }^{26}$. Do czasu wyjaśnienia niepewnych aspektów wiążących się z wzajemnym uznawaniem dokumentów urzędowych na obszarze UE w niektórych państwach członkowskich można spodziewać się odmowy przyznawania mocy dowodowej dokumentom wystawianym przez krajowe organy niebędace sądami ${ }^{27}$. W ocenie niektórych przedstawicieli nauki wobec próby wprowadzenia bardziej szczegółowych wytycznych problematyczna może okazać się mnogość i różnorodność dopuszczalnych rozrządzeń mortis causa w porządkach prawnych Unii Europejskiej oraz odmienności w prawie cywilnym procesowym $^{28}$. W każdym z państw ten cel może być realizowany $\mathrm{w}$ nieco odmienny sposób. Aby móc rozstrzygnąć o autentyczności dokumentu, organ krajowy powinien mieć rozeznanie $\mathrm{w}$ sposobach dysponowania swoim majątkiem na wypadek śmierci w poszczególnych krajach $\mathrm{UE}^{29}$.

${ }^{26}$ I tak, do czasu wydania przez TSUE w dniu 17 stycznia 2019 r. orzeczenia w sprawie C-102/18 (ECLI:EU:C:2019:34) nie było jednoznaczne, czy przy składaniu wniosków o wydanie Europejskiego poświadczenia spadkowego stosowanie formularzy, o których mowa w załącznikach do rozporządzenia wykonawczego 1329/2014, jest obligatoryjne, czy też fakultatywne.

${ }^{27}$ M. Margoński: Art. 62, w: Prawo i postępowanie spadkowe. Komentarz...

${ }^{28}$ K. Flaga-Gieruszczyńska: Europejskie poświadczenie spadkowe - zagadnienia wybrane. W: Notarialne poświadczenie dziedziczenia. Red. A. Marciniak..., s. 17 i n. Na różnorodność rozwiązań prawnych przyjętych w poszczególnych państwach członkowskich w zakresie postępowań dotyczących europejskiego poświadczenia spadkowego zwraca również uwagę T. Kot: Czy polski notariusz może być sqdem..., s. 86 i n., a szczegółowo prezentuja je P. Rylski, K. Weitz: Postępowania dotyczqce europejskiego poświadczenia spadkowego - rozporzadzenie nr 650/2012 a prawo krajowe (szkic prawnoporównawczy). „Przegląd Sądowy” 2018, nr 4, s. 42.

${ }^{29}$ Legislacyjne luki unijnego prawodawcy związane z dokumentami urzędowymi wydawanymi przez organy krajowe są zauważalne także w innych sprawach, dotyczacych punktów stycznych pomiędzy statutem spadkowym a innymi statutami, rozstrzyganych przez Trybunał na przestrzeni ostatnich lat. Dowodzi tego m.in. kazus Kubicka (Wyrok TSUE z dnia 12 października 2017 r. w sprawie C-218/16. ECLI:EU:C:2017:755), w którym sąd występujący z pytaniem prejudycjalnym zwrócił uwagę na niekompletność regulacji UE względem różnorodnych porządków prawnych w państwach członkowskich. Przedmiotem wątpliwości stała się dopuszczalność nabycia udziału w nieruchomości położonej w Niemczech w drodze zapisu windykacyjnego zawartego w testamencie sporządzonym przez obywatelkę polską przed polskim notariuszem. Uznanie takiego dokumentu za ważna podstawę nabycia własności nieruchomości położonej w Niemczech powodowałoby problemy w odniesieniu do wpływu prawa dotyczącego rejestru nieruchomości na skuteczność rozrządzenia testamentowego. Prawo niemieckie nie przewiduje takiej podstawy nabycia prawa rzeczowego, a w Rozporządzeniu wskazane jest, że zgodnie z art. 1 ust. 2 lit. k, „charakter praw rzeczowych” jest wyłączony z zakresu jego zastosowania. Tym samym niejasne stało się, czy państwo miejsca położenia nierucho- 
Istotne jest, że korzystanie z europejskich instrumentów harmonizacyjnych $\mathrm{w}$ zakresie prawa spadkowego nie jest możliwe bez wprowadzania zmian w prawie krajowym, aby przystosować je do realizacji celu Rozporządzenia polegającego na ułatwieniu swobodnego przepływu osób oraz dokumentów w sprawach spadkowych mających skutki transgraniczne. Wprowadzenie europejskiego poświadczenia spadkowego wiązało się np. z koniecznością dokonania zmian w niemieckiej ustawie wskazującej dokumenty, które mogą być podstawą wpisu prawa własności do księgi wieczystej ${ }^{30}$. Na marginesie należy zaznaczyć, że także w polskiej ustawie o księgach wieczystych i hipotece ${ }^{31}$ nie zostały dotychczas wprowadzone zmiany wskazujące europejskie poświadczenie spadkowe jako jedną z podstaw wpisu do księgi wieczystej.

\section{Uwagi końcowe}

Jak wskazano wcześniej, w kontekście sprawy C-658/17 dostrzec można zaledwie jeden $\mathrm{z}$ wielu problemów związanych z zastosowaniem zagranicznych dokumentów urzędowych do spraw spadkowych o charakterze transgranicznym. Wątpliwości budzi również sam charakter prawny poświadczenia ${ }^{32}$. W nauce proponuje się, aby nie kwalifikować go ani jako „orzeczenie”, ani jako „dokument urzędowy”, lecz przyjąć, że stanowi ono „tytuł sui generis”, odrębny zarówno od orzeczeń sądowych, jak i dokumentów urzędowych, który może być każdocześnie zmieniony lub uchylony ${ }^{33}$. De lege ferenda również to zagadnienie zasługuje na uczynienie go przedmiotem wykładni Trybunału.

Rozporządzenie 650/2012, nadając przede wszystkim notariuszom znaczące uprawnienia w zakresie stwierdzania autentyczności doku-

mości ma możliwość kwestionowania skutku rzeczowego zapisu windykacyjnego umieszczonego w dokumencie sporządzonym przez uprawniony organ państwowy (notariusza). W orzeczeniu w tej sprawie Trybunał wskazał, że prawu wybranemu przez spadkodawcę powinien podlegać ogół praw dotyczących dziedziczenia - w tym także sposób przechodzenia składników majątku na spadkobierców, a w określonych przypadkach — również na zapisobierców.

${ }^{30}$ Chodzi tutaj o $\$ 35$ niemieckiej ustawy Grundbuchordnung in der Fassung der Bekanntmachung vom 26. Mai 1994, https://www.gesetze-im-internet.de/gbo/ BJNR001390897.html.

${ }^{31}$ T.j. Dz.U. 2019, poz. 2204.

${ }_{32}$ M. Margoński, w: Prawo i postępowanie spadkowe. Komentarz. T. 4 b. Red. K. Osajda..., s. 100.

${ }^{33}$ Ibidem. 
mentów oraz wydawania europejskich poświadczeń spadkowych, otwiera przed przedstawicielami tej profesji nowe możliwości i czyni istotny krok w kierunku europeizacji notariatu, przełamujac tym samym do pewnego stopnia krajowy monopol w zakresie czynności notarialnych. Glosowane orzeczenie przecina dotychczasowe wątpliwości odnoszące się do statusu prawnego notariusza. Należy jednak zaznaczyć, że wykładnia dokonana przez Trybunał odnosi się wyłącznie do regulacji Rozporządzenia i z pewnością nie zakończy dostrzegalnych od lat doktrynalnych sporów $\mathrm{w}$ tym przedmiocie. Stanowisko zakreślone przez Trybunał w sprawie C-658/17 zasługuje na pozytywną ocenę. Jak wskazano powyżej, normy Rozporządzenia nie precyzuja pewnych istotnych aspektów dotyczących jego stosowania przez organy krajowe, a przepisy wykonawcze zawarte w prawie polskim należy uznać za niewystarczające. Jeżeli luka pomiędzy teoretycznymi a praktycznymi aspektami implementacji nie zostanie zredukowana, poświadczenie zamiast stać się innowacyjnym rozwiązaniem prawnym, które pozwoli uniknąć kolizji prawa w Europie, stanie się zaledwie ideologicznym projektem ${ }^{34}$. Prócz dalszych zmian legislacyjnych, mających na celu ułatwienie sukcesji po osobach, których działalność skoncentrowana była w więcej niż jednym państwie, pożądana jest dalsza aktywność Trybunału, który przez swoje orzecznictwo czuwa nad koherencją prawa UE. Współcześnie, w erze „europejskich nomadów”, w której obywatele nie tylko swobodnie przemieszczają się na terenie Unii Europejskiej, lecz także lokują kapitał w innych krajach, szczególnie ważne jest zaakceptowanie konsekwencji, które wynikają z takiego stanu rzeczy, i dostosowywanie praw krajowych do europejskich regulacji. Zaniechanie takich działań może mieć wpływ na niechętne posługiwanie się nowymi instrumentami przez organy państw członkowskich, co w konsekwencji skutkować będzie żmudnymi i zawiłymi transgranicznymi postępowaniami spadkowymi. Do momentu dostosowania przepisów krajowych do nowej sytuacji prawnej ciężar należytej interpretacji Rozporządzenia w przeważającej mierze spoczywał będzie na Trybunale. Jako jedyny jest on władny rozstrzygać wątpliwości związane z interpretacją przepisów Rozporządzenia i należy wyrazić nadzieję, że zostaną one uczynione przedmiotem kolejnych rozstrzygnięć w przyszłości.

34 Ibidem. 


\section{Bibliografia}

\section{Literatura}

Borkowski P.: Notarialne poświadczenie dziedziczenia. Warszawa 2011.

Carruthers J.M., Crawford E.B.: Speculation on the Operation of Succession Regulation 650/2012: Tales of Unexpected. „22 European Review of Private Law" 2014, Issue 6.

Czubik P.: Konsekwencje europejskiego rozporzadzenia spadkowego ( $n$ r 650/ 2012) dla praktyki notarialnej (zagadnienia dotyczace wyboru prawa wtaściwego dla dziedziczenia). „Rejent” 2013, nr 11.

Księżak P.: Charakter prawny aktu poświadczenia dziedziczenia. W: Notarialne poświadczenie dziedziczenia. Zagadnienia wybrane. Red. A. Marciniak. Warszawa 2019.

Notarialne poświadczenie dziedziczenia. Red. A. Marciniak. Warszawa 2019.

Nowe europejskie prawo spadkowe. Red. J. Górecki, M. Pazdan. Warszawa 2015.

Pazdan M.: Notarialne poświadczenie dziedziczenia po zmianach z 2015 roku. „Rejent” 2016, nr 4.

Pisuliński J.: Europejskie prawo cywilne. Warszawa 2013.

Prawo i postępowanie spadkowe. Komentarz. T. 4 b. Red. K. Osajda. Warszawa 2019.

Rylski P., Weitz K.: Postępowania dotyczqce europejskiego poświadczenia spadkowego - rozporzadzenie nr 650/2012 a prawo krajowe (szkic prawnoporównawczy). „Przegląd Sądowy” 2018, nr 4.

Setkowicz M.: Notariusz jako organ ochrony prawnej w świetle prawa polskiego i prawa Unii Europejskiej. „Przegląd Prawa i Administracji” 2016, T. 107.

Szereda A.: Czynności notarialne. Komentarz do art. 79-112 Prawa o notariacie. Warszawa 2018.

Trocha B.: Akt poświadczenia dziedziczenia w świetle prawa UE. Glosa do wyroku TS z dnia 23 maja 2019 r., C-658/17. LEX.

Załucki M.: New revolutionary regulation on succession matters. Key issues and doubts. „Revista de derecho civil” 2016, vol. 3, $\mathrm{n}^{\circ} 1$.

Znad granicy ponad granicami. Księga jubileuszowa Profesora Dietera Martiny. Red. M. Krzymuski, M. Margoński. Warszawa 2014.

\section{Orzecznictwo}

Postanowienie Sądu Okręgowego w Gliwicach z dnia 19 kwietnia 2017 r., III Ca 391/17.

Wyrok Trybunału Konstytucyjnego z dnia 10 grudnia 2003 r., K 49/2001. OTK ZU 2003, nr 9A, poz. 101. 
Wyrok TSUE z dnia 9 marca 2017 r., C-484/15. ECLI:EU:C:2017:199.

Wyrok TSUE z dnia 9 marca 2017 r., C-551/15. ECLI:EU:C:2017:193.

Wyrok TSUE z dnia 12 października 2017 r. w sprawie C-218/16. ECLI:EU:C: 2017:755.

Wyrok TSUE z dnia 17 stycznia 2019 r., C-102/18. ECLI:EU:C:2019:34.

Wyrok TSUE z dnia 23 maja 2019 r. w sprawie WB, C-658/17. ECLI:EU:C: 2019:444

\section{Akty prawne}

Grundbuchordnung in der Fassung der Bekanntmachung vom 26. Mai 1994, https://www.gesetze-im-internet.de/gbo/BJNR001390897.html.

Rozporządzenie Parlamentu Europejskiego i Rady (UE) nr 650/2012 z dnia 4 lipca 2012 r. w sprawie jurysdykcji, prawa właściwego, uznawania i wykonywania orzeczeń, przyjmowania i wykonywania dokumentów urzędowych dotyczaccych dziedziczenia oraz w sprawie ustanowienia europejskiego poświadczenia spadkowego. Dz.Urz. UE L nr 201 z 2012 r., s. 107.

Ustawa z dnia 14 lutego 1991 r. - Prawo o notariacie. T.j. Dz.U. 2019, poz. 540, 730, 1495, 1655, 2020. 